\title{
The Death of the Da'i: The Autonomization of Religious Messages within Cyberspace
}

\author{
Fazlul Rahman \\ Institut Agama Islam Syarifuddin, Lumajang \\ Email: fazlulrahman85@gmail.com
}

\begin{abstract}
Abs tract: This paper attempts to explore the phenomenon of Islamic propagation (dakwah) on the Internet known as "e-dakwah." It problematizes the authority of religious messages within cyberspace vis a vis Internet's anonymity. This 'cyber ethnographic' research shows that people in cyberscape are concerned more with the messages than their authors. This study confirms the autonomic truth of the messages as it is supported by Imam 'Alī bin Abī Ṭālib's popular argument "listen to what has been said, not who has said that." Consequently, the truth and acceptance of it in the dakwah activities or messages within cyberspace does not depend on the preacher s $\left(d \bar{a}^{\prime} \bar{\imath}\right)$ and their professional capacity and intellectual knowledge, but on the object of dakwah (mad' $\bar{u}$ ). This paper proposes the term "The death of the da' $i$," which is adapted from Roland Barthes' term "The death of the author" in his image-music-text, to discuss the phenomenon.
\end{abstract}

Keywords: cyberspace, religious messages, response, and anonymity

DOI: https://doi.org/10.20414/ujis.v22i2.313

\section{Introduction}

GLOBALIZATION, which is marked by the innovation of information and communication technology, provides simplicity and easiness to human's life. Nowadays, information from all over the world can be accessed directly through our screens (televisions, computers, even cellular phones). The world now, as it is imagined by Marshall McLuhan, is like a "global village"1 which has no space and time boundaries. ${ }^{2}$

1 The term "global village," introduced by Marshall McLuhan for his optimistic view toward the current technology development. This optimistic view 
Mass media is one aspect of a human's life, which shows great progress. Beginning from the invention of telegraph by Samuel F. B. Morse in the middle of eighteen century, and the invention of mechanical movable type printing by Gutenberg in the same century, mass media has taken a dominant part in human's life. Then came the invention of radio-which could record, produce, and transmit sound-came in 1920, the invention of television, film and cinema that could produce sound and motion pictures and in the end of sixties ${ }^{3}$ the Internet came with the multi abilities (to produce texts, sounds, and motion pictures). ${ }^{4}$ All these innovations have created specific contacts between people and media. ${ }^{5}$

Recently, many products of mass media come along with the needs of the society to information. Each product competes in promoting up-to-date information, easy access, and low costs. Internet, at this point, is the most favorite among other products. It can be seen clearly from the data of internet penetration and total users all over the world. Data from www.internetworldstats.com shows that total Internet users in the world on December 31, 2000, is $360,985,492$ and on December 31, 2017, it rises to $4,156,932,140$.

is contradictory with William Gibson, Mark Slouka and others, who see the current technology development skeptically. To see clearly about this contradictory, see: Stanley J. Baran, Introduction to Mass Communication: Media Literacy and Culture (New York: McGraw-Hill, 2004), 298-299, and compare it with Mark Slouka, Ruang yang Hilang: Pandangan Humanis tentang Budaya Cyberspace yang Merisaukan (Bandung: Mizan, 1995), and Astar Hadi, Matinya Dunia Cyberspace: Kritik Humanis Mark Slouka terhadap Jagat Maya (Yogyakarta: LKiS, 2005).

${ }^{2}$ Mode rnity requires a new concept of "space" itself, see Anthony Giddens, The Consequences of Modernity (California: Standford University Press, 1990), 14.

3 To know further about the history of the Internet, see: Micheal A. Banks, On the Way to the Web: The Secret History of the Internet and Its Founders (United States of America: Apress, 2008).

${ }_{4}^{4}$ Nuruddin, Pengantar Komunikasi Massa (Jakarta: RajaGrafindo Persada, 2007), 59-60, compare it with Asa Briggs and Peter Burke, A Social History of the Media (New York: Polity Press, 2000).

5 Melfin L. DeFleur and Everette E. Dennis, Understanding Mass Communication (Boston: Houghton Mifflin Company, n.d.), 3. 
The number means that Internet users in the world grown up to $1.052 \%$ in the last eighteen years ${ }^{6}$

Many facilities provided by the Internet really attract many people (no matter how old are they, where they live, what their job, and any other boundaries) to use the Internet and to go online. This condition naturally has raised the so-called "cyber community."7 Do not want to leave behind, those "religious surfers" come together to join this new community. As Lorne L. Dawson mentioned, at least there are five promises provided by the Internet for religion: ${ }^{8}$ spreading the Word, building new communities, boundary-breaking, virtual rituals and fostering a new religious consciousness.

A surprising fact about religion on the Internet was released by the Pew Internet and American Life Project, ${ }^{9}$ which shows that some 28 million Americans have used the Internet to get religious and spiritual information and to connect with others on their faith journeys. Larsen called them "Religion Surfers,"10 who think key spiritual resources are more readily available online than offline. ${ }^{11}$

${ }^{6}$ To know the detailabout the Internet usage statistics in the world, please visit:: www.Internetworldstats.com

${ }^{7}$ Likely the same with what happened in real life, the cyber community also has its own social rule. For further information about the term "cybercommunity," see Burhan Bungin, Sosiologi Komunikasi: Teori, Paradigma, dan Diskursus Teknologi Komunikasi di Masyarakat (Jakarta: Kencana Prenada Media Group, 2006), 159.

${ }^{8}$ Lorne L. Dawson, “Doing Religion in Cyberspace: The Promise and the Perils," The Council of Societies for the Study of Religion Bullet in 30, no. 1 (2001): 3-9, and compare it with Syarif Hidayatullah and Zulfikar S. Dharmawan, Islam Virtual: Keberadaan Dunia Islam di Internet (Ciputat: Mifta, 2004).

9 See http://www.pewInternet.org/reports/reports.asp, Elena Larsen, "Cyberfaith: How Americans Pursue Religion Online," in Religion Online: Finding Faith on the Internet, ed. Lorne L. Dawson and Douglas E. Cowan (New York: Routledge, 2004), 17-20.

${ }^{10} 25 \%$ of Internet users have gotten religious or spiritual information online at one point or another. More than 3 million people a day get religious or spiritual material, up from the 2 million that reported last year. For comparison's sake, it is interesting to note that more people have gotten religious or spiritual information online than have gambled online, used Web auction sites, traded stocks online, placed phone calls on the Internet, done online banking, or used Internet-based dating services.

${ }^{11} 64 \%$ of Religion Surfers believe that the Internet provides easier access to 
The facts as mentioned above give us a new perspective about the Internet and Religion, that Internet has become a new fertile land and even a primary need for the development of religion, ${ }^{12}$ inter-faith dialogue, ${ }^{13}$ and a perfect space for "the business of religion." 14 This fertility has been supported by the openness of the Internet for anybody. Once one has a unit of computer, modem, or phone line, he/she can start surfing online.

The openness of the Internet gives positive implications with the consideration of one Islamic teaching to spread the message of Allah even one simple verse. ${ }^{15}$ Many websites contain Islamic articles proves that the Internet is pro-Islam. However, this openness unconsciously has caused a crisis of authority and authenticity of religion. ${ }^{16}$ Previously, the meanings of religious teachings belonged to the interpretation of certain people's authority, who have a great qualification of Islamic sciences and good social piety, as mentioned by dakwah theory which requires a great qualification of Islamic sciences and good behavior to be a successful $d \bar{a} \bar{\imath}^{\prime}{ }^{17}$ The dakwah theory is also supported by a

religious study and educational materials rather than they can otherwise find offline. Nearly half ( $44 \%$ ) be lieve that the Internet provides easier access to prayer and other de votional ma terials than they can otherwise find offline. Nonmembers of religious organizations rely on the internet to find resources that members of actual congregations are likely to find in their faith communities. 11.

12 Brenda E. Brasher, Give Me That Online (San Fransisco: Jossey-Bass, 2001),

${ }^{13}$ Sukidi Imawan, Teologi Inklusif Cak Nur (Jakarta: Penerbit Buku Kompas, 2000).

${ }^{14}$ For further information about this kind of business, see Mara Einstein, Brands of Faith: Marketing Religion in a Commercial Age (New York: Routledge, 2008), 13.

15 As the Prophet Muhammad said, “بلّنوا عنّي ولو أية" (to te ach others about Me even only one verse). Hadis no. 3274, see Abū 'Abd Allāh Muhammad ibn Ismā'̂̂l ibn Ibrāhīm ibn al-Mughīrah ibn Bardizbah al-Ju'fī al-Bukhārī, Al-Jāmi' Al-Ṣaḥ̄h Al-Mukhtașar (Beirut: Dār Ibnu Kathir, 1978).

16 See Lorne L. Dawson and Cowan Douglas E., eds., Religion Online: Finding Faith on the Internet (New York: Routledge, 2004), 2.

17 Muḥammad Rajab al-Shatiwi, al-Da"wah al-Islāmiyyah fī Daw"i al-Kitāb wa al-Sunnah (Cairo: Dār al-Ṭibā'ah al-Muhammadiyyah, 1990); Muhammad Amhazūn, Manhaj al-Nab̄̄ fī Da'wah min Khilāl al-Sìrah al-Ṣaḥịhah (Cairo: Dār alSalām, 2003); 'Abdullah Nāṣih 'Ulwān, Silsilah Madrasah al-Du'āt (Cairo: Dār alSalām, 2004); 'Abdul Karīm Zaydān, Ușūl al-Da'wah (Beirut: Muassasah al- 
communication theory which asserts that "achieving a maximum target in the communication process, the message should be sent by a credible and attractive communicator. ${ }^{18}$ All these conditions, unfortunately, will not suitable in cyberspace at all.

In cyberspace, anyone (even without any qualifications) may send religious messages. There is no obligation for people to attach their real identity on their messages and telling us that some messages are allowed and some others are not. In consequence, we cannot distinguish the good $d \bar{a}^{\prime} \hat{\imath}$ from the bad one. ${ }^{19}$ The inevitable anonymity of the Internet messages, ${ }^{20}$ make this problem even more complicated. Considering the inevitable anonymity of the Internet, it is then essential to question who has the authority to interpret those religious messages in cyberspace?

\section{Methodology}

Referring to John D. Brawer, ${ }^{21}$ In this research, I use "cyber ethnography"22 involving an in-depth interview and participant

Risālah, 2001).

18 Stanley J. Baran, Self, Symbols \& Society (London: Addison-Wesley Publishing Company, Inc., 1984); Gene C. Whaples and Einar R. Ryden, “Attitude Change: Your Challenge," Journal of Extension, no. Nove mber/December (1975): 12-17, https://joe.org/joe/1975november/1975-6-a2.pdf; Thomson and Megan M., "Attitudes and Attitude Change: Implications for the OSSIS Speakers Bureau Programme," in Defence RED Canada - Toronto, Technical Memorandum DRDC Toronto TM 2003 - 126, 2003; CarlI. Hovland and Walter Weiss, "The Influence of Source Credibility on Communication Effectiveness," Public Opinion Quarterly 15, no. 4 (1951): 635-650.

19 According to Jum 'ah Amīn 'Abd al- 'Azīz the term "dā'iyah" in Arabic terminology shows two kinds of da'i, dai, who call for the truth and the other call for heresy, see Jum'ah Amīn 'Abd al-'Azīz, \ial-Da'wah: Qawā'id wa Ușul (Alexandria: Dār al-Da‘wah, 1999), 18.

20 Jennifer L. Mnookin, "Virtual(ly) Law: The Emergence of Law in LambdaMOO: Mnookin," Journal of Computer-Mediated Communication 2, no. 1 (1996), https://onlinelibrary.wiley.com/doi/abs/10.1111/j.1083-6101.1996.tb00185.x.

${ }^{21}$ Brawer said that to access social meanings, to observe behavior and work as professional with the informants, there are many relevant methods to collect data, such as participant observation, in-depth interview, using personal documents and discourse analysis natural languages. See John. D. Brewer, Ethnography (Philadelphia: Open University Press, n.d.).

${ }^{22}$ Using ethnography for research in cyberspace - as mentioned by Wittelis appropriate with the flexible concept of "field" in ethnographic studies and it is 
observation with the informants in cyberspace to access social meanings and behavior of certain cybercommunity.

Technically, in doing an in-depth interview, I used nonprobability sampling method which means taking the sample based on specific considerations. ${ }^{23}$ I mean by considerations here are some criteria proposed by Spradley for determining "good informant" for ethnographic interviews, such complete inculturation, direct involvement, unknown culture settings, time efficiency and non-analytic. ${ }^{24}$

The interview conducted in Islam Chat room of Yahoo Messenger (Yahoo Messenger/ Yahoo Chat/ Categories: Religion \& Belief/ Islam Chat) with the consideration that Islam Chat is a specialized room for discussing Islam in Yahoo Messenger. It was conducted in November-December 2010, using three different languages (Bahasa, English, and Arabic). Among 70 interviewees, there were only 31 valid interviews collected during the period. That refers to some barriers found during the interview:

applicable for "cyberspace," see: Andreas Wittel, "Ethnography on the Move: From Field to Net to Internet," Forum Qualitative Sozialforschung / Forum: Qualitative Social Research 1, no. 1 (January 31, 2000), http://www.qualitativeresearch.net/index.php/fqs/article/view/1131, compare it with Annette Markham, "Reconsidering Self and Other: The Methods, Politics, and Ethics of Representation in Online Ethnography," in Handbook of Qualitative Research, ed. N.K. Denzin and Y.S. Lincoln (Thousand Oaks: Sage, 2004), Christine Hine, Virtual Ethnography (London, Thousand Oaks \& New Delhi: Sage Publications Inc, 2000), Kate Eichhorn, "Sites Unseen: Ethnographic Research in a Textual Community," International Journal of Qualitative Studies in Education 14, no. 4 (July 1, 2001): 565-578, https://doi.org/10.1080/09518390110047075, Adi Kuntsman, "Cyberethnography as Home-Work," Anthropology Matters 6, no. 2 (2004): 1-10, accessed January 6 , 2019, https://www.anthropologymatters.com/index.php/anth_matters/article/view/97. Also, cyber ethnography itself assumed that wath happend in cyberspace is not different from it in reallife, see: Allison Cavanagh, "Behavior in Public?: Ethics in Online Ethnography," Cybersociology 6, no. 2 (1992), http://www.cybersociology.com/files/6_2_ethicsinonlineethnog.html(12 February 2010).

${ }^{23}$ Jalaludin Rakhmat, Metode Penelitian Komunikasi (Bandung: Remaja Rosdakarya, 1989), 107.

${ }^{24}$ James P. Spradley, The Etnographic Interview, trans. Misbah Zulfa Elizabeth (Yogyakarta: Tiara Wacana, 2006), 68-77. 
1. Internet connection lost

2. Interviewee's decision not to talk to males

3. Interviewee's signing out of Yahoo Messenger with no clues

4. Interviewee's consideration that religion is a privacy

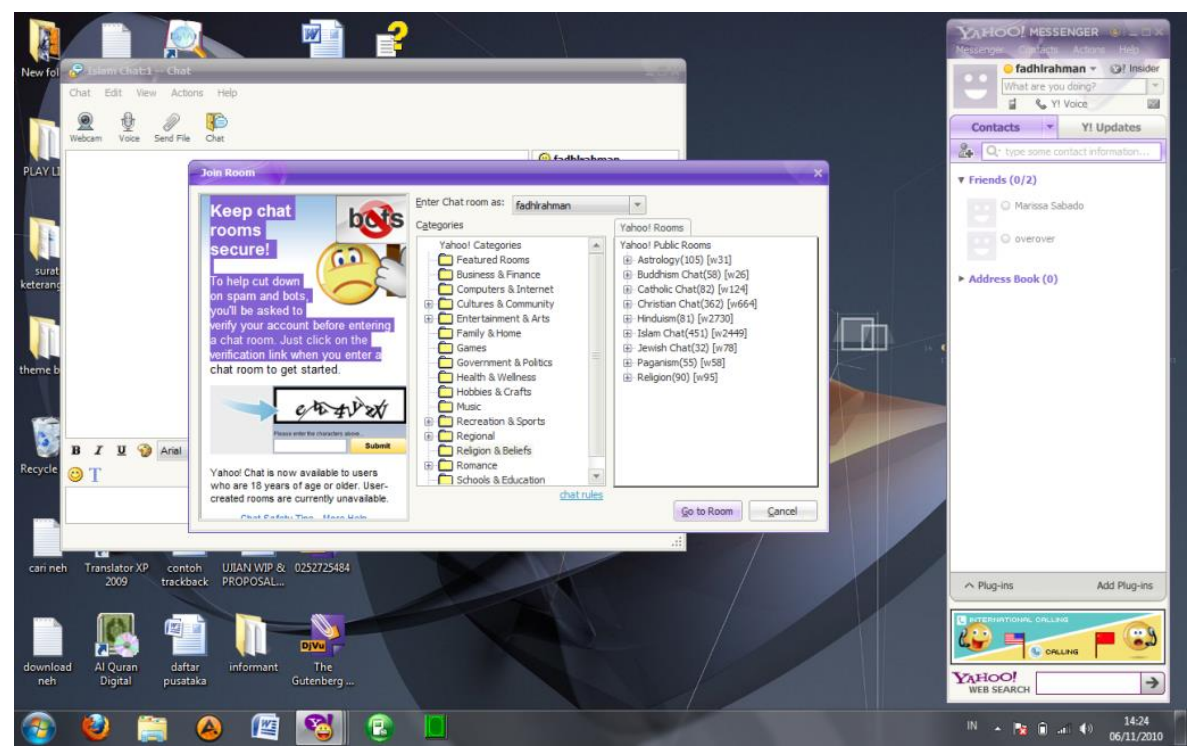

Figure 1.

Islam Chat Room in Yahoo Messenger

Besides doing an in-depth interview with the informants in cyberspace, I also created a "web-based survey" using the facility of Google Document addressed in https://spreadsheets.google. com/viewform?formkey=dGJTWFRUNThJUXdkR2dvYXpOYmFs NFE6MQ and spread it to 39 mailing lists. These 39 mailing lists are randomly chosen by typing the term "dakwah," "Islam," in Yahoo Groups search engine and some big universities' mailing lists in Indonesia, such as University of Indonesia, Gadjah Mada University, Syarif Hidayatullah State Islamic University. To gain more data, I spread the link of this web-based survey to 415 people in my Facebook friend list account. The web-based survey first opened in $1^{\text {st January }} 2011$ and officially closed in 31 January 2011 with 118 valid responses in the survey and 32 valid responses sent through Facebook's inbox. 


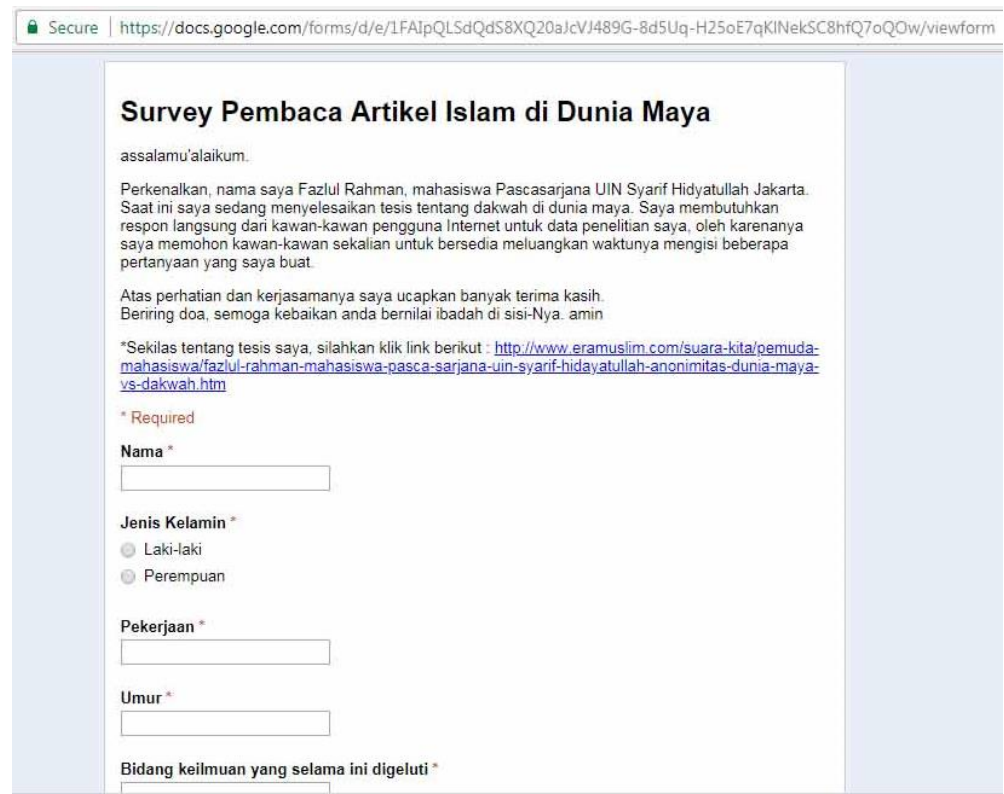

Figure 2.

Web-Based Survey

"Survey Form of Readers of internet-based Islam"

All the collected data were analyzed using communication and ethnographic approach-or as Bakti called it "ethnomethodology." 25 The approach is an important thing to do, because the message, Internet and dakwah are parts of communication studies. Furthermore, an ethnographic approach is used-as a function of ethnography itself - to build a systemic understanding about human's culture from insiders' point of view. ${ }^{26}$

\section{Response In Communication and Dakwah's Studies}

The term "communication," which means an exchange of thought, feeling or information between one and the others that have common meanings and target, ${ }^{27}$ has many classifications ${ }^{28}$

25 Andi Faisal Bakti, Communication and Family Planning in Islam in Indonesia: South Sulawesi Muslim Perceptions of a Global Development Program (Jakarta: INIS, 2004), 217-219.

${ }_{26}$ Spradley, The Etnographic Interview, 13.

27 There are many definitions for the term "communication" based on who and from what angle he/she sees the term. For example, see: Sarbaugh, 
including the communication of dakwah. As a process, communication involves at least five elements; the sender (communicator), message, media, receiver (communicant) and response (effects). ${ }^{29}$ Among these five, the response is the most critical element to know the effectiveness of the communication. ${ }^{30}$ In other words, we may confidently argue that the response is the primary goal of the communication process ${ }^{31}$

In the communication discourse, the message itself (orally, written or symbolic) sometimes has been found problematic. One of the immerging problems is the recipients' response toward the messages. Many theories produced to explain this, such as the $S$ O-R (Stimulus-Organism-Response) theory. This theory says that the effect (of communication) is a specific reaction caused by a specific stimulus. Therefore, one could expect and predict the correlation between message and communicant's reaction. The

Intercultural Communication (New Jersey: Haydon Book Company Inc, 1993), 2; Dani Vardiansyah, Pengantar Ilmu Komunikasi (Bogor: Ghalia Indonesia, 2004); Onong Uchjana Effendy, Dinamika Komunikasi (Bandung: Remaja Rosdakarya, 2008), 4; Stanley J. Baran, Jerilyn S. Mclntyre, and Timothy P. Meyer, Self, Symbols and Society: An Introduction to Mass Communication (London: Addison-Wesley Publishing Company, Inc., 1984), 19; Denis McQuail and Seven Windahl, Communication Models for Study of Mass Communications (New York: Longman, 1993), 5. Aubrey Fisher said that the phenomenon fo communication is a different phenomenon. We can see it cle a rly from many concepts of communication. In the middle of the 20th century, for example, to define a communication term become popular among communication scientist. Dance and Larson, in Miller, reported more than 126 definitions proposed in literature - as cited by Elvinaro Ardianto and Bambang Q. Anees, Filsafat Ilmu Komunikasi (Bandung: Simbiosa Rekatama Media, 2007), 17.

${ }^{28}$ Further information about the se classifications of communication, see Anwar Arifin, Ilmu Komunikasi: Sebuah Pengantar Singkat (Jakarta: Raja Grafindo Persada, 2006).

${ }^{29}$ As Lasswell said that the appropriate way to illustrate the communication process is by answering the questions below: (Who), (Says what), (In what channel), (To whom), (With what effect), see: McQuail and Windahl, Communication Models, 13; John. R. Bittner, Mass Communication, an Introduction (New Jersey: A Division of Simon \& Shuster, Inc., 1986), 15.

${ }^{30}$ Arvind Kumar, Encyclopedia of Mass Media and Communication (New Delhi: Anmol Publication PVT. LTD., 1998), vol.2, 149; Campbell and Hapler, Dimensions in Communication (California: Wadsworth Publishing Company, 1969), 43.

31 John Vivian, Teori Komunikasi Massa, trans. Tri Wibisono B.S (Jakarta: Kencana, 2008), 464. 
elements of this model are Message (stimulus, S), Communicant (organism, $\mathrm{O}$ ), and Effect (response, $\mathrm{R}$ ).

The diagram below explains how the communicants respond the message:

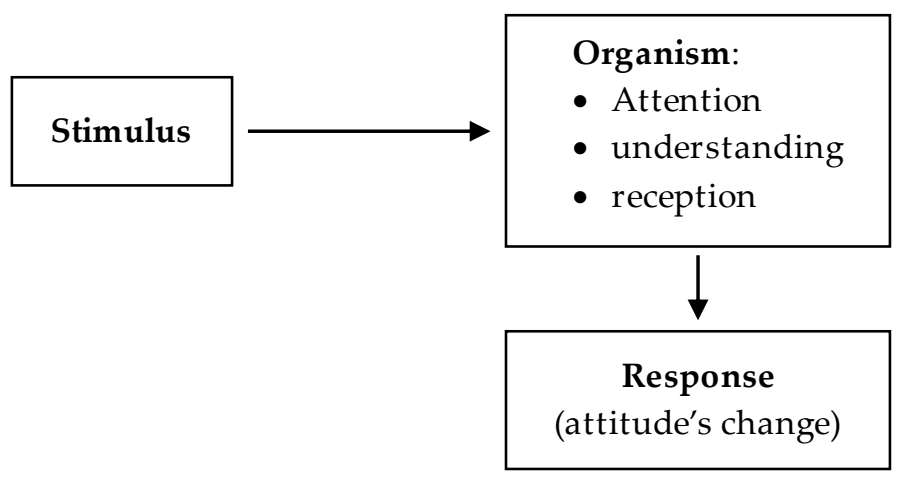

Figure 3.

The process of S-O-R theory

The above diagram clearly shows that the messages will go through several phases before the communicants respond to the messages. The expected response of the messages will not always be the same with the given stimulus, and even, communicants may utterly refuse the message and give no response. This theory, interestingly, emphasizes the significant role of the communicant in filtering the message.

Different from S-O-R theory, which stresses the role of communicant, the mass communication studies mostly acknowledge "the bullet theory," which argues that communicants had no significant role in the communication process. It is called "bullet" theory because it sees that communicants passively respond to the fusillade of mass media messages. The primary assumption of this theory is that the components of communication (communicator, message and media) significantly influence the passive communicants. ${ }^{32}$

In 1967, using a $Q$-sort data collection procedure, William Stephenson conducted extensive research on audiences' attitude

\footnotetext{
${ }^{32}$ Rakhmat, Metode Penelitian Komunikasi, 83.
} 
toward the media. From this research, Stephenson developed a "play theory," 33 showing that, the use of media as a tool to refrain and to escape from a busy world to "a play world." This theory inspires the future theory focusing on how the media is used and what kind of gratification can be gained from the media, which known as "uses and gratification theory."

The uses and gratification theory claims that the media does not do anything to people, but people do things to the media. ${ }^{34}$ In other words, the effect of media is limited to what people permit to happen. This theory begins from the idea that everyone is an active selector to the media (entirely different from the bullet theory's point of view) and the audiences actively respond to the messages in the media.

There are three theoretical assumptions brought by uses and gratification theory. First, the audience of mass communication is active and goal-directed. Second, the audience of the member is responsible mainly for choosing the media to meet their needs. The third assumption, related to the other two, is that media compete with other sources to gratify audiences' needs. In other words, despite various options to gratify peoples' needs provided by the media, it is still the people hold final decision which to choose.

Going in the same vein as uses and gratification theory, Thayer, ${ }^{35}$ Ravault, Hall, ${ }^{36}$ Katz and Liebes, ${ }^{37}$ Ang, ${ }^{38}$ and also Bakti

${ }^{33}$ William Stephenson, The Play Theory of Mass Communication (Chicago: The University of Chicago Press, 1967).

34 Elihu Katz, Jay Blumler, and Michael Gurevitc, "Uses of Mass Communication by the Individual," in Mass Communication Research: Major Issues and Future Directions, ed. W. P. Davidson and F. Yu (New York: Praeger, 1974), 11-35.

35 Lee Thayer, Communication and Communication Systems in Organization, Management, and Interpersonal Relations (Homewood, Illinois: Richard D. Irwin, INC., 1968).

${ }^{36}$ Stuart Hall, "Encoding/Decoding," in Culture, Media, Language, ed. Stuart Hall, et al (New York: Routledge, 1980).

37 Elihu Katz and T. Liebes, "Mutual Aid in the Decoding of Dallas: Preliminary Notes from a Cross-Cultural Study," in Television in Transition, ed. P. Drummond and R. Paterson (London: BFI Books, 1986), 187-280.

38 Ien Ang, "The Nature of the Audience," in Questioning the Media, ed. J. Downing et al (Newbury Park: Sage Publications Inc, 1990), 155-165. 
propose the "active-recipient theory," which believes that mass media are not as powerful as they are imagined, their receivers are not passive but active, even, they may give a contradictory responses-as explained by the "boomerang effects theory." Bakti, in this context, stresses the fact that messages cannot be decoded equally, since the meanings are culturally, politically, socially, and psychologically contextualized by the individual recipient's circumstances. ${ }^{39}$

This active-recipient theory believed that receivers are not passive while receiving the messages. It is because-according to Thayer-the traditional model of communication $(\mathrm{A} \rightarrow \mathrm{B}=\mathrm{X})$ is faulty or inadequate on some counts:

First, the Stimulus $\rightarrow$ Response $(\mathrm{A} \rightarrow \mathrm{B})$ model of communication just doesn't fit the facts. $A$ may say something to $B$. We would not want to question the "reality" of $A$ 's utterance. However, we also need to understand that what $B$ hears or how he interprets what he hears is ultimately a product of $B$ and not of $A$. Second, we have to recognize the fact that $A$ 's utterance does not fall upon even a temporarily inactive or relatively "blank" mind. Quite the contrary. A's statement can be meaningful to $B$ only to the extent that (1) $B$ has developed over time the required mental "wherewithal" to apprehend and comprehend $A$ 's utterance in the context in which it occurs; and (2) B's mind is active. Third, it should be evident that who is doing the communicating has considerable upon how $B$ interprets the utterance. One can readily accept a controversial statement made by a friend, but might boldly disagree with the same statement made by someone he/she dislikes or distrusts. ${ }^{40}$ Based on those previous theories (on how individuals actively respond to the messages in a communication process) in mind, now I would like to critically see how mad'u (as the receiver) respond to the religious messages from the dás'

Theoretically, dakwah activity is the communication process in its particular understanding. ${ }^{41}$ Therefore to give a

\footnotetext{
${ }^{39}$ Bakti, Communication and Family, 108, 113-117.

40 Thayer, Communication and Communication Systems, 24-26.

${ }^{41}$ M. Bahri Ghazali, Da'wah Komunikatif: Membangun Kerangka Dasar Ilmu Komunikasi Da'wah (Jakarta: Pedoman Ilmu Jaya, 1997), 13.
} 
comprehensive understanding of how the communicant from responding to the messages, we will see how the response (of the message) in dakwah studies.

Regarding the Islamic history, the successfulness of dakwah has been depended on the $d \bar{a} ' \hat{\imath}$ (as a subject of dakwah). ${ }^{42}$ Thus, to give a maximum result, the message of dakwah should be delivered by those $d \bar{a} ' \bar{\imath} s$ who have high qualification in Islamic sciences and good spirituality. ${ }^{43}$ However, at this point, I would like to argue that the phenomenon of using technologies in dakwah activities, such as the use of the Internet for dakwah, has given us a new paradigm of the dakwah successfulness. In this context, the $d \bar{a} ' \bar{\imath}$ is no longer the main factor for dakwah messages to be wholly accepted by mad' $\bar{u}$ (the recipient of dakwah messages) since mad' $\bar{u}$ critically responds the dakwah messages by interpreting those messages according to his/her needs.

Ali bin Abi Thalib's popular argument "see what has been said NOT to see who has said"44 encourages readers to be active and objective recipients while receiving the messages, without being affected by the message senders. For Muslims, this argument is obviously following the teaching of Islam as mentioned in some Quranic verses: (Q.S al-A'lā, 9), ${ }^{45}$ (al-Ghāshiyah, 22-23), ${ }^{46}$ and (Āli 'Imrān, 20). ${ }^{47}$

42 Hasanuddin, Manajemen Dakwah (Ciputat: UIN Jakarta Press, 2005), 79; Fathul Bari An-Nabiry, Meniti Jalan Dakwah: Bekal Perjuangan Para Da'i (Jakarta: Amzah, 2008), 134.

43 al-Shatiwi, al-Da'wah al-Islāmiyyah; Amḥazūn, Manhaj al-Nabī; 'Ulwān, Silsilah Madrasah al-Du'āt; Zaydān, Ușūl al-Da'wah; 'Ali 'Abdul Ḥalīm Maḥmūd, Figh al-Da'wah al-Fardiyyah (Mesir: Dār al-Wafā', 1992); Ahmad Ahmad Ghalwush, al-Da "wah al-Islāmiyyah: Ușūluhā wa Wasā"iluhā (Cairo: Dār al-Kutub al-Mașrī, 1987).

${ }^{44}$ Abdul Wahīd bin Muhammad bin 'Abd al-Wahīd al-Aqdamī al-Tamīmī, Ghurar al-Hikam wa Durar al-Kalim (Maṭba'ah al-'Irfan, 1931) Fashl 85 ha dits no. 40 "Lā tanẓur ilā man qāla wa unẓur ilā mā qīla."

45 "therefore do remind, surely reminding does profit" them."

46 "Therefore do remind, for you are only a reminder, you are not a watcher over

47 "Upon you is only the delivery of the message." 


\section{Cyber-cleric Under the Shadow of Anonymity}

Following the example of the dakwah of the Prophet Muhammad (PBUH), there are at least two determinant factors of his successful dakwah activities. First, Muhammad's consistency to do dakwah code of ethics. Second, Muhammad's exemplary for his companions.

The term dakwah code of ethics refers to some of the Quranic guidance on dakwah activities. Ali Mustafa Yaqub said that there are, at least, seven dakwah codes of ethics according to the Quran; not to be inconsistent between words and actions (Q.s. al-Baqarah, 44; al-Șaff, 2-3), not to abuse those whom they call upon besides Allah (al-An'ām, 108), not to expect for rewards (Q.s. Saba', 47, Shu'arā', 109, 127, 145, 164, 180 and Hūd, 29 \& 51), not to compromise in matters of faith (Q.s. al-Kāfirūn, 1-6), not to do any social discrimination (Q.s. 'Abasa, 1-2, al-An'ām, 52, and al-Kahfi, 28), not to be a friend with the immoral (Q.s. al-Mā'idah, 78-79), not to deliver the unknown things (Q.s. al-Isrā', 36). ${ }^{48}$ Further, Tata Sukayat said that $d \bar{a}$ 's $\bar{s}$ should have, at least, 35 kinds of virtues and avoid 42 kinds of disgraceful characters. ${ }^{49}$ Fuad Kauma said that there are 15 kinds of evil characters might destroy the sacred image of the "ulama. 50

Those factors as mentioned above, I would like to underline, unfortunately, may not be applicable when the $d \bar{a} \hat{\imath}$ go into the cyberspace because the cyberspace is naturally a cross-geographic, ethnic, and ethics space. People could not differentiate the "true $d \bar{a}^{\prime} \bar{l}^{\prime \prime}$ from the fake ones in this space, moreover, to ensure their dakwah code of ethics.

On the other hand, the anonymity of the internet is irresistible, and it is widely agreed that it becomes one of the users' rights to

48 Ali Mustafa Yaqub, Sejarah dan Metode Dakwah Nabi (Jakarta: Pustaka Firdaus, 2008), 223.

${ }^{49}$ For more detail, see: Sukayat, Tata Quantum Dakwah (Jakarta: Rineka Cipta, 2009), 58-83. Compare it with Maḥmūd 'Abd al-Lațîf 'Uwayḍah, Hamlu al-Da'wah al-Islāmiyyah: Wājibāat wa Șifāt (Beirut: Dār al-Ummah, 1996); Amḥazūn, Manhaj alNabī; 'Ulwān, Silsilah Madrasah al-Du'āt; Maḥmūd, Fiqh al-Da'wah al-Fardiyyah; Ghalwush, al-Da'wah al-Islāmiyyah; Moh. Ardani, Memahami Permasalahan Fikih Dakwah (Mitra Cahaya Utama, 2006).

${ }^{50}$ Fuad Kauma, Noda-Noda Ulama (Bandung: Remaja Rosdakarya, 2002). 
be anonymous. In short, it has been and always be an integrated part of the Internet, any efforts to drag it out of Internet obviously would give no results. In the context of dakwah, this condition is indeed a big challenge for the Muslim cyber clerics. So how $d \bar{a} ' \bar{\imath}$ address this issue?

To answer this, first of all, I would like to underline the fact that the most common ways to do dakwah in the cyberspace (even there are many facilities could be used for dakwah) is by delivering religious messages through articles on websites, blogs or mailing lists. Consequently, the $d \bar{a}^{\prime} \bar{\imath}$ should be able to provide religious articles that could meet their cyber communities' tastes.

Based on this research, there are some requirements for religious articles to be able to meet the cyber communities' taste. Interviews with the netters and the web-based survey conducted in this research reveal that there are at least five important criteria of an excellent online religious article:

1. Valid. The article should not only be informative but also supported by authoritative and valid references from Quran, Sunnah, or any other Islamic references.

2. Objective. The article should be able to provide a comprehensive, smart, and inspiring analysis of the topic being discussed. That also should be free from the subjective dogma of particular Muslim groups.

3. Contextual. The readers prefer to read articles about Islam that are relevant to their current social contexts. Because, most of the time, they expect some answers to their current problems while reading the articles.

4. The article should be presented in a peaceful way of writing, using standard and understandable terminologies and less Arabic terms. Also, it will be more attractive if the article complemented with some visualizations (like picture, voice, or video).

5. Last but not least, a good article according to the netizen, should have a clear identity. Not only the identity of the article's author but more than that, the identity of the 
supporting organization of the website that publishes the article.

Putting those characteristics into account, we may conclude that the so-called dakwah code of ethics and exemplary of $d \bar{a} ' \bar{\imath}$ are not applicable in cyberspace and that, basically, due to the absence of the $d \bar{a} ' \hat{\imath}$ physical existence. However, the absence of the $d \bar{a} ' \hat{\imath}$ does not influence the objective receptions of their messages. The data illustrates that $57 \%$ of the respondents see that the messages are more important than the authors themselves. On the other hand, $11 \%$ of them view the importance of the authors more than the messages. Meanwhile, $27 \%$ view both messages and authors are equally important.

Following up this finding, I would argue that readers' objectivity toward the message gives a positive implication on bringing back the objective meaning of the message regardless their subjectivity, fanaticism and the authority of the authors. Regarding the influence of the author, $49 \%$ of the respondents admitted that the authors indeed influenced their understanding of the messages. Meanwhile, $29 \%$ of them admitted the contrary.

Other than giving positive implication on the objective meanings of the article, this finding also confirms the validity of S$\mathrm{O}-\mathrm{R}$ theory, the uses and gratification theory and also the activerecipient theory, which emphasize on the critical attitude of the readers. They respond the message not with "blank mind" as Lee Thayer said :

"The objects and events of our worlds are entire without meaning in their raw event-data form. It is people who create and attach or assign meaningfulness to them. The way a person puts words together is a product of him. However, the way in which a receiver understands those words is a function of the receiver, not of the originator. The originator may create the event-data, but the receiver creates the meaning that event-data has for him. Moreover, that is what counts in communication." ${ }^{51}$

In the context of dakwah, this finding confirms my hypothesis that the greatness and the attractiveness of the $d \bar{a}^{\prime} \hat{\imath}$ are less important compared to mad'u quality in processing and

\footnotetext{
${ }^{51}$ Thayer, Communication and Communication Systems, 36.
} 
interpreting the message. Therefore, the successfulness of dakwah no longer depends on the da' $\bar{\imath}$ but mad' $\bar{u}$. In such cross-identity space, $\mathrm{mad}^{\prime} \bar{u} /$ communicants freely explore many things for his/her spiritual needs with less attention to the quality of the $d \bar{a}^{\prime} \hat{\imath}$ behind the messages. I call this phenomenon as the death of the $d \bar{a}^{\prime} \bar{\imath}$.

\section{Conclusion}

The doctrine of the universality of Islam should not be understood only from its substantial meaning that Islam is relevant for all times and places (șālih li kullizamān wa makān), but also from the fact that dakwah of Islam should cover anyone in the world, including the digital world or cyberspace. The rejuvenation of dakwah methods at this point becomes the necessary corollary to the intersection of Islam and current technology, only then, Islam will stand still in front of the unstoppable development of technology. This current research on how Muslims respond to religious messages in cyberspace becomes one manifest token of how dakwah activity should be seriously revisited.

One explicit consideration this article would like to emphasize is that Muslims in the digital era should be the active receivers of religious messages. They are strongly encouraged to actively contextualize what they got about religion from any media channels. The death of the $d \bar{a} ' \bar{\imath}$, in this context, should be followed with the rise of the better mad' $\bar{u}$. Because, answering this paper's main question, mad' $\bar{u}$ holds the absolute authority to interpret the religious messages in cyberspace. Here, media literacy becomes socially and religiously compulsive project to educate Muslims to wisely use the media and finally able to comprehensively understands and produce a comprehensive interpretation of religious messages in cyberspace.

\section{References}

'Abd al-'Azīz, Jum'ah Amīn. al-Da'wah: Qawā'id wa Ușul. Alexandria: Dār al-Da'wah, 1999.

Amḥazūn, Muḥammad. Manhaj al-Nabī fì Da'wah min Khilāl al-Sīrah al-Ṣaḥihah. Cairo: Dār al-Salām, 2003. 
Ang, Ien. "The Nature of the Audience." In Questioning the Media, edited by J. Downing et al, 155-165. Newbury Park: Sage Publications Inc, 1990.

An-Nabiry, Fathul Bari. Meniti Jalan Dakwah: Bekal Perjuangan Para $D \bar{a} \hat{\imath}$. Jakarta: Amzah, 2008.

Ardani, Moh. Memahami Permasalahan Fikih Dakwah. Mitra Cahaya Utama, 2006.

Ardianto, Elvinaro, and Bambang Q. Anees. Filsafat Ilmu Komunikasi. Bandung: Simbiosa Rekatama Media, 2007.

Arifin, Anwar. Ilmu Komunikasi: Sebuah Pengantar Singkat. Jakarta: Raja Grafindo Persada, 2006.

Bakti, Andi Faisal. Communication and Family Planning in Islam in Indonesia: South Sulawesi Muslim Perceptions of a Global Development Program. Jakarta: INIS, 2004.

Banks, Micheal A. On the Way to the Web: The Secret History of the Internet and Its Founders. United States of America: Apress, 2008.

Baran, Stanley J. Introduction to Mass Communication: Media Literacy and Culture. New York: McGraw-Hill, 2004.

- - . Self, Symbols \& Society. London: Addison-Wesley Publishing Company, Inc., 1984.

Baran, Stanley J., Jerilyn S. Mclntyre, and Timothy P. Meyer. Self, Symbols and Society: An Introduction to Mass Communication. London: Addison-Wesley Publishing Company, Inc., 1984.

Bittner, John. R. Mass Communication, an Introduction. New Jersey: A Division of Simon \& Shuster, Inc., 1986.

Brasher, Brenda E. Give Me That Online. San Fransisco: Jossey-Bass, 2001.

Brewer, John. D. Ethnography. Philadelphia: Open University Press, n.d.

Briggs, Asa, and Peter Burke. A Social History of the Media. New York: Polity Press, 2000.

al-Bukhārī, Abū 'Abd Allāh Muḥammad ibn Ismā'îl ibn Ibrāhīm ibn al-Mughīrah ibn Bardizbah al-Ju'fī. Al-Jāmi' Al-Ṣaḥīh AlMukhtașar. Beirut: Dār Ibnu Kathir, 1978.

Bungin, Burhan. Sosiologi Komunikasi: Teori, Paradigma, dan Diskursus Teknologi Komunikasi di Masyarakat. Jakarta: Kencana Prenada Media Group, 2006. 
Campbell, and Hapler. Dimensions in Communication. California: Wadsworth Publishing Company, 1969.

Cavanagh, Allison. "Behavior in Public?: Ethics in Online Ethnography." Cybersociology 6, no. 2 (1992).

Dawson, Lorne L. "Doing Religion in Cyberspace: The Promise and the Perils." The Council of Societies for the Study of Religion Bulletin 30, no. 1 (2001): 3-9.

Dawson, Lorne L., and Cowan Douglas E., eds. Religion Online: Finding Faith on the Internet. New York: Routledge, 2004.

DeFleur, Melfin L., and Everette E. Dennis. Understanding Mass Communication. Boston: Houghton Mifflin Company, n.d.

Effendy, Onong Uchjana. Dinamika Komunikasi. Bandung: Remaja Rosdakarya, 2008.

Eichhorn, Kate. "Sites Unseen: Ethnographic Research in a Textual Community." International Journal of Qualitative Studies in Education 14, no. 4 (July 1, 2001): 565-578. https://doi.org/ 10.1080/09518390110047075.

Einstein, Mara. Brands of Faith: Marketing Religion in a Commercial Age. New York: Routledge, 2008.

Ghalwush, Ahmad Ahmad. al-Da"wah al-Islāmiyyah: Ușūluhā wa Wasā"iluhā. Cairo: Dār al-Kutub al-Mașrī, 1987.

Ghazali, M. Bahri. Da'wah Komunikatif: Membangun Kerangka Dasar Ilmu Komunikasi Da'wah. Jakarta: Pedoman Ilmu Jaya, 1997.

Giddens, Anthony. The Consequences of Modernity. California: Standford University Press, 1990.

Hadi, Astar. Matinya Dunia Cyberspace: Kritik Humanis Mark Slouka terhadap Jagat Maya. Yogyakarta: LKiS, 2005.

Hall, Stuart. "Encoding/Decoding." In Culture, Media, Language, edited by Stuart Hall, et al. New York: Routledge, 1980.

Hasanuddin. Manajemen Dakwah. Ciputat: UIN Jakarta Press, 2005. Hidayatullah, Syarif, and Zulfikar S. Dharmawan. Islam Virtual: Keberadaan Dunia Islam di Internet. Ciputat: Mifta, 2004.

Hine, Christine. Virtual Ethnography. London, Thousand Oaks \& New Delhi: Sage Publications Inc, 2000.

Hovland, Carl I., and Walter Weiss. "The Influence of Source Credibility on Communication Effectiveness." Public Opinion Quarterly 15, no. 4 (1951): 635-650. 
Imawan, Sukidi. Teologi Inklusif Cak Nur. Jakarta: Penerbit Buku Kompas, 2000.

Katz, Elihu, Jay Blumler, and Michael Gurevitc. “Uses of Mass Communication by the Individual." In Mass Communication Research: Major Issues and Future Directions, edited by W. P. Davidson and F. Yu. New York: Praeger, 1974.

Katz, Elihu, and T. Liebes. "Mutual Aid in the Decoding of Dallas: Preliminary Notes from a Cross-Cultural Study." In Television in Transition, edited by P. Drummond and R. Paterson. London: BFI Books, 1986.

Kauma, Fuad. Noda-Noda Ulama. Bandung: Remaja Rosdakarya, 2002.

Kumar, Arvind. Encyclopedia of Mass Media and Communication. New Delhi: Anmol Publication PVT. LTD., 1998.

Kuntsman, Adi. "Cyberethnography as Home-Work." Anthropology Matters 6, no. 2 (2004): 1-10. Accessed January 6, 2019.

https://www.anthropologymatters.com/index.php/anth_matter s/article/view/97.

Larsen, Elena. "Cyberfaith: How Americans Pursue Religion Online." In Religion Online: Finding Faith on the Internet, edited by Lorne L. Dawson and Douglas E. Cowan, 17-20. New York: Routledge, 2004.

Mạ̣mūd, 'Ali 'Abdul Ḥalīm. Fiqh al-Da'wah al-Fardiyyah. Mesir: Dār al-Wafā', 1992.

Markham, Annette. "Reconsidering Self and Other: The Methods, Politics, and Ethics of Representation in Online Ethnography." In Handbook of Qualitative Research, edited by N.K. Denzin and Y.S. Lincoln. Thousand Oaks: Sage, 2004.

McQuail, Denis, and Seven Windahl. Communication Models for Study of Mass Communications. New York: Longman, 1993.

Mnookin, Jennifer L. "Virtual(ly) Law: The Emergence of Law in LambdaMOO: Mnookin." Journal of Computer-Mediated Communication 2, no. 1 (1996). https://onlinelibrary. wiley.com/doi/abs/10.1111/j.1083-6101.1996.tb00185.x.

Nuruddin. Pengantar Komunikasi Massa. Jakarta: RajaGrafindo Persada, 2007. 
Rakhmat, Jalaludin. Metode Penelitian Komunikasi. Bandung: Remaja Rosdakarya, 1989.

Sarbaugh. Intercultural Communication. New Jersey: Haydon Book Company Inc, 1993.

al-Shatiwi, Muhammad Rajab. al-Da "wah al-Islāmiyyah fì Daw"i al-

Kitāb wa al-Sunnah. Cairo: Dār al-Ṭibā’ah al-Muhammadiyyah, 1990.

Slouka, Mark. Ruang yang Hilang: Pandangan Humanis tentang Budaya Cyberspace yang Merisaukan. Bandung: Mizan, 1995.

Spradley, James P. The Etnographic Interview. Translated by Misbah Zulfa Elizabeth. Yogyakarta: Tiara Wacana, 2006.

Stephenson, William. The Play Theory of Mass Communication.

Chicago: The University of Chicago Press, 1967.

Sukayat. Tata Quantum Dakwah. Jakarta: Rineka Cipta, 2009.

al-Tamīmī, Abdul Wahīd bin Muḥammad bin 'Abd al-Wahīd alAqdamī. Ghurar al-Hikam wa Durar al-Kalim. Mațba'ah al-'Irfan, 1931.

Thayer, Lee. Communication and Communication Systems in Organization, Management, and Interpersonal Relations. Homewood, Illinois: Richard D. Irwin, INC., 1968.

Thomson, and Megan M. "Attitudes and Attitude Change: Implications for the OSSIS Speakers Bureau Programme." In Defence RED Canada - Toronto, Technical Memorandum DRDC Toronto TM 2003 - 126, 2003.

'Ulwān, 'Abdullah Nāṣih. Silsilah Madrasah al-Du'āt. Cairo: Dār alSalām, 2004.

'Uwayḍah, Mạ̣mūd 'Abd al-Lațîf. Hamlu al-Da'wah al-Islāmiyyah:

Wājibāt wa Sifāt. Beirut: Dār al-Ummah, 1996.

Vardiansyah, Dani. Pengantar Ilmu Komunikasi. Bogor: Ghalia Indonesia, 2004.

Vivian, John. Teori Komunikasi Massa. Translated by Tri Wibisono B.S. Jakarta: Kencana, 2008.

Whaples, Gene C., and Einar R. Ryden. "Attitude Change: Your Challenge." Journal of Extension, no. November/December (1975): 12-17. https://joe.org/joe/1975november/1975-6-a2.pdf. Wittel, Andreas. "Ethnography on the Move: From Field to Net to Internet." Forum Qualitative Sozialforschung / Forum: Qualitative 
Social Research 1, no. 1 (January 31, 2000). http://www. qualitative-research.net/index.php/fqs/article/view/1131. Yaqub, Ali Mustafa. Sejarah dan Metode Dakwah Nabi. Jakarta: Pustaka Firdaus, 2008.

Zaydān, 'Abdul Karīm. Ușūl al-Da'wah. Beirut: Muassasah alRisālah, 2001. 